FINAL/DEFINITIVE VERSION: Aaron Winter (2014), 'My Enemies Must Be Friends: The American Extreme Right, Conspiracy Theory, Islam and the Middle East', Conspiracy Theories in the Middle East and the United States, eds, M. Reinkowski and M. Butter, Berlin: de Gruyter. pp. 35-58.

http://www.degruyter.com/view/product/212554

\title{
My Enemies Must Be Friends: The American Extreme-Right, Conspiracy Theory, Islam, and the Middle East
}

Aaron Winter (Abertay)

That's really a true American: George Lincoln Rockwell

I know for a fact he hates Commies cus he picketed the movie Exodus

Bob Dylan, “Talkin’ John Birch Paranoid Blues”

Whether they articulate fears about freed slaves, Jews, freemasons, communists, civil rights, the federal government, the "New World Order", or "Zionist Occupied Government" (ZOG), conspiracy theories have always been central to the American extreme-right. The extreme-right is a diverse group of right-wing movements, most notably white supremacists, white nationalists, white separatists, and neo-Nazis such as the Ku Klux Klan, American Nazi Party, National Alliance, Aryan Nations, and others who hold racist and/or anti-Semitic views, ideologies, and conspiracist interpretations and theories of history and power. ${ }^{1}$ Such extreme-right movements and organizations have emerged and proliferated at different points throughout American history whenever they perceive social, political, or economic developments as detrimental to the white race and/or America, from Reconstruction in the 1860s-70s through civil rights in the 1960s and the farm crisis in the 1980s to the election of Barack Obama in 2008.

Conspiracy theories have provided a vehicle for the expression and representation of the extremeright's fears about threats to white supremacy and America and served as justification for their political mobilization, activism, and violence. While the conspirators in such theories have included internal and external enemies or threats, there has been a consistent stable of usual suspects that relate to America's racial, political, ideological, and regional fault-lines. Even though there have been both internal enemies and allies in such theories, external forces are rarely portrayed as anything but a threat. Following 9/11, alQaeda, 'Islamist' Extremists, the Middle East, and the wider Muslim and Arab world began to feature more prominently in extreme-right conspiracy theories and literature. While the mainstream right feared the threat posed by this region and people, the extreme-right saw them as potential allies in their war against the American government and Zionism. In response, watchdogs, academics, and other commentators have made a great deal about the link between extreme-right and Islamist conspiracy theories and potential alliances between the two movements, not just post-9/11 but retrospectively throughout the post-war era.

In this chapter, I examine American extreme-right conspiracy theories concerning the Middle East and the Muslim and Arab world, attempted alliances with Islamists and the relationship between such

\footnotetext{
${ }^{1}$ Cf. Martin Durham, The Christian Right, the Far Right and the Boundaries of American Conservatism, Manchester 2000, p. xii.
} 
theories and alliances, as well as work by commentators who attempt to establish links between the extreme-right and Islamists based on their shared penchant for conspiracy theories and efforts towards alliance building. I argue that in spite of claims about overlap and alliances, attempts to forge alliances between the extreme-right and Islamists have been unidirectional, originating with the extreme-right, and largely unsuccessful. Moreover, they have tended to occur during (and thus reflect) periods of movement realignment or crisis, when the extreme-right is seeking political direction and relevance. These are periods which correspond to developments and realignments in American foreign policy and international relations that concern the Middle East and Islam. In Part One, I examine attempts by commentators to establish links between conspiracy theories, extremism and political alliances and between the extreme-right and Islamists. This is followed in Part Two with an examination of attempts by the extreme-right to form alliance with movements in the Arab and Muslim world, as well as conspiracy theories about them, in five specific periods of realignment or crisis in the post-war period: post-World War II, post-Civil Rights, postCold War, post-9/11, and following the election of Barack Obama.

\section{Part 1: Conspiracies, Theories, and Alliances}

Since the events of $9 / 11$, a great amount of attention has been paid not only to Islamist terrorism and extremism in the Middle East, Arab and Muslim world, but to conspiracy theories there about 9/11, American foreign policy and Jews, Zionism, and Israel. High profile examples include theories that claim 9/11 was an American and/or Israeli plot, the anti-Semitic conspiracy theory Protocols of the Elders of Zion promoted on jihadist websites, Radio Islam, and, in a dramatization, on Hizballah TV soon after 9/11, as well as Holocaust denial by Iranian President Mahmoud Ahmadinejad in a 2005 speech and during his 2006 Holocaust conference in Iran. In a speech made at the UN in New York in September 2010, Ahmadinejad also claimed that the US government was behind 9/11 in order to prop up Israel.

Since 9/11, this phenomenon has been examined and commented on in numerous books and articles on Islamist extremism, conspiracy theory and the relationship between them - a topic first written about by Daniel Pipes in The Hidden Hand: Middle East Fears of Conspiracy (1996) - most notably Matthew Gray's Conspiracy Theories in the Arab World: Sources and Politics (2010). The link has also been discussed in the increasing number of books and articles on conspiracy theory that came out post9/11, such as David Aaronovitch's Voodoo Histories: How Conspiracy Theory Has Shaped Modern History (2009). Aaronovitch argues that "[a]ll sorts of conspiracy theories were springing up around the attack on the World Trade Center and the subsequent invasion of Afghanistan, theories that seemed to me potentially dangerous in the world view they expounded". ${ }^{2}$ Aaronovitch views conspiracy theory as an attack on enlightenment reason and democratic discourse and practice, targeting in particular the West, Israel and Zionism, the Anglo-American coalition, and the war on terror. Aaronovitch posits, in agreement

\footnotetext{
${ }^{2}$ David Aaronovitch, Voodoo Histories: How Conspiracy Theory Has Shaped Modern History, London 2009 , p. 3.
} 
with Daniel Pipes, that the Middle East is “awash" with conspiracy theories, ${ }^{3}$ but that post-9/11 "[w]e in West are currently going through a period of fashionable conspiracism" as well. ${ }^{4}$ Thus, in addition to his examination of conspiracy theory in the Middle East and amongst Islamists, he also looks at the 9/11 'Truthers', the anti-war left, and the extreme-right in the West.

Aaronovitch sees an overlap between Islamism and the extreme-right in anti-Semitic conspiracy theories such as the Protocols of Zion, ${ }^{5}$ as does Mark Levin in the HBO documentary Protocols of Zion (2004). In the film, which begins in New York City at the site where the World Trade Center stood, Levin traces 9/11 conspiracy theories concerning Jews back to the original Protocols, a forged document about a meeting between Jewish leaders in which they formulate a plot for world domination, first published in Russia by agents of the Czar in 1905. Levin then traces the Protocols to its publication in the US in 1919 in the form of Henry Ford's "The International Jew" in the Dearborn Independent, to its instrumentalization by Nazi Germany, and eventually its revival, dissemination and use by contemporary Muslim leaders, Jihadist websites, and American neo-Nazis such as Shaun Walker of the National Alliance and Frank Weltner of JewWatch.com. ${ }^{6}$

Aaronovitch and Levin are not alone in linking conspiracy theory and extremism and finding overlap between Islamists and the extreme-right. Others include Martin Lee in "The Swastika and the Crescent" (2002), George Michael in The Enemy of My Enemy: The Alarming Convergence of Militant Islam and the Extreme-right (2007), and Daniel Pipes in "The Far Right and Jihadis in Alliance", "More Ties between Islamists and Neo-Nazis", and "CAIR Promotes and Hosts William W. Baker, Neo-Nazi". Yet, these three find more than overlap between the two movements: they are concerned about alliances between them. This concern emerged almost immediately following 9/11, when extreme-right activists issued statements which not only celebrated the attacks, but also extended a hand of friendship to al-Qaeda and other Islamists. One example cited by these and other commentators came from Billy Roper of the National Alliance:

The enemy of our enemy is, for now at least, our friend. We may not want them marrying our daughters, just as they would not want us marrying theirs. We may not want them in our societies, just as they would not want us in theirs [...] But anyone who is willing to drive a plane into a building to kill jews is alright by me. I wish our members had half as much testicular fortitude. ${ }^{7}$

\footnotetext{
${ }^{3}$ Aaronovitch, Voodoo Histories, p. 8.

${ }^{4}$ Aaronovitch, Voodoo Histories, p. 3.

${ }^{5}$ Cf. Aaronovitch, Voodoo Histories, p. 1.

${ }^{6}$ Cf. Mark Levin, The Protocols of Zion, HBO, USA, 2004. It should be noted that there is a lack of consensus on origins of the Protocols with some scholars putting them in France in the eighteenth century and others in Russia in the nineteenth or early twentieth century.

${ }^{7}$ Southern Poverty Law Center (SPLC), "Reaping the Whirlwind”, in: Intelligence Report, 2001, http://www.splcenter.org/intelligenceproject/ip-4t3.html (accessed Dec. 10, 2008).
} 
The notion that shared enemies provide a basis for an alliance between the extreme-right and Islamists is central to the analysis of Lee, Michael, and Pipes. Despite focusing primarily on the European extremeright, Lee discusses the American scene as well and argues that "[ $\mathrm{t}] \mathrm{he}$ peculiar bond between white nationalist groups and certain Muslim extremists derives in part from a shared set of enemies - Jews, the United States, race-mixing and ethnic diversity". This point not just ignores the racial, ethnic, and national diversity of Islam, but also implies that in principle both the extreme-right and Islamists would oppose any co-existence, if not also co-operation, with each other based on their respective racial and ethnic differences. In addition to this, Lee argues that "[b]oth sets of groups also have a penchant for far-flung conspiracy theories that caricature Jewish power". He claims that "[t]he psychological dynamics that propel the actions of Islamic terrorists have much in common with the mental outlook of neo-Nazis" since, he writes, "[b]oth glorify violence as a regenerative force and both are willing to slaughter innocents in the name of creating a new social order". Although initially merely stating that the two movements are a peculiar match due to their shared insularity and xenophobia, he eventually argues that because of these common characteristics and historical links between Nazis and Muslims " $[\mathrm{t}]$ he potential for an alliance between American neo-Nazis and Islamic terrorists - an alliance that could develop into strong operational ties - cannot be ruled out". 8

Like Lee, Michael holds that, in spite of clear differences on issues of race and religion, the two movements have a clear overlap if not convergence on several important issues, such as their utopian desire for homogeneous societies and support for Palestinian independence, their critique of American foreign policy and military intervention in the Middle East, the American media, modernity, secularism, and globalization, and their anti-Semitic conspiracy theories about Jewish and/or Zionist control over the US and the New World Order. ${ }^{9}$ Michael argues that such overlap "could presage greater cooperation between the two movements in the future. Such an alliance, if properly organized and coordinated, could pose a significant challenge to the status quo not only in the United States but in Europe as well", ${ }^{10}$ and that "by aligning itself with militant Islam, the extreme-right could conceivably ride on the coattails of a dynamic movement". ${ }^{11}$ What was clear from Roper's statement and his expression of both admiration for 9/11 and regret that his movement lacked the "testicular fortitude" to do so, was that he wanted to ride on al Qaeda's coattails and become friends if not allies.

While Lee and Michael look for potential alliances between the extreme-right and Islamists, Pipes investigates what he terms "the neo-Nazi affection for radical Islam", and tries to prove existing alliances

\footnotetext{
${ }^{8}$ Martin Lee, “The Swastika and the Crescent”, in: Intelligence Report 105/2002, http://www.splcenter.org/get-informed/intelligence-report/browse-all-issues/2002/spring/the-swastika-andthe-crescent/ (accessed Dec. 10, 2010).

${ }^{9} \mathrm{Cf}$. George Michael, The Enemy of My Enemy: The Alarming Convergence of Militant Islam and the Extreme-right, Lawrence 2006, pp. 2-3, 9.

${ }^{10}$ Michael, The Enemy of My Enemy, p. 3.

${ }^{11}$ Michael, The Enemy of My Enemy, p. 172.
} 
and conspiracies between them. ${ }^{12}$ In his various articles, Pipes cites as evidence their shared anti-Semitism and conspiracy theories, statements issued by right-wing extremists following 9/11, reports from Europe, anecdotes, Michael's book, ${ }^{13}$ as well as the example of Canadian right-wing extremist William Baker visiting alleged Islamists in America. ${ }^{14}$ One could argue that by imagining plots and accumulating evidence from diverse and somewhat unconnected sources in order to prove the existence of these plots, Pipes is operating as a conspiracy theorist himself.

In such work about alliances, the authors look not only at statements of intent - such as Roper's and common characteristics, but for concrete evidence. Looking at history, they attempt to construct a narrative of overlap, relations, and alliances between Nazis and Arabs and Muslims. For Lee, the origins of the overlap and potential for alliances lie in the fact that the growth of the Muslim Brotherhood in Egypt, which had a "fascistic ideology", and fascism in Europe not only coincided historically, but that the Brotherhood's founder Hassan al-Banna allegedly collaborated with the Third Reich and the Grand Mufti of Jerusalem supported Hitler. According to Lee, Hitler overcame his dislike of Arabs because both had the same enemies - British, communists, and Jews -, and thus formed an alliance articulated by "the old Arab adage $[\ldots]$ 'the enemy of my enemy is my Friend". ${ }^{15}$ That connection even entered the popular vernacular following 9/11 when the term "Islamo-fascist" came into use, creating a direct link between America's greatest enemies of the twentieth and twenty-first century, Nazism and Islamism. Following this example from the Second World War, both Lee and Michael travel through America, Europe, and the Muslim world, from the cold war to $9 / 11$, citing examples of statements of intent to establish links between American right-wing extremists, Arab and Muslims leaders, and Islamists.

Yet, Michael argues that attempts to build alliances in the Middle East have produced few tangible results. "Although the extreme-right and militant Islam on occasion share rhetoric", Michael writes, "what admiration does exist tends to move in one direction: selected extreme-right activists voice support for militant Islam, but the latter rarely voices support for the former". ${ }^{16} \mathrm{He}$ also points out that some Islamists have reached out in an effort to build a "broad-based anti-Zionist coalition", ${ }^{17}$ but concrete examples have mainly been in the area of Holocaust denial (e.g. Ahmed Rami of Radio Islam speaking at the Historical Review conference in 1992 and David Duke attending Ahmadinejad's Holocaust conference in 2006) and conspiracy theory.

\footnotetext{
${ }^{12}$ Daniel Pipes, “The Far Right and Jihadis in Alliance”, Mar. 9, 2005, updated Apr. 15, 2011, http://www.danielpipes.org/blog/2005/03/the-far-right-jihadis-in-alliance (accessed Dec. 16, 2011).

${ }^{13}$ Cf. Pipes, "The Far Right"; Pipes, "More Ties between Islamists and Neo-Nazis", Jan. 8, 2004, http://www.danielpipes.org/blog/2004/01/more-ties-between-islamists-and neo-nazis (accessed Aug. 16, 2010).

${ }^{14}$ Cf. Pipes, "CAIR Promotes and Hosts William W. Baker, Neo-Nazi”, March 9, 2004, http://www.danielpipes.org/blog/2004/03/cair-promotes-and-hosts-william-w-baker-neo-nazi (accessed Aug. 16, 2010).

${ }^{15}$ Lee, "The Swastika and the Crescent".

${ }^{16}$ Michael, The Enemy of My Enemy, p. 138.

${ }^{17}$ Michael, The Enemy of My Enemy, p. 130.
} 
As noted, Aaronovitch, Pipes, Michael, and Lee all argue that conspiracy theory (specific theories, overlapping theories, or the mere penchant for them) is a significant link between Islamists and the extreme-right and evidence of potential or actual alliances. Conspiracy theories are significant as they are widely viewed by commentators and watchdogs as embodying and thus serving as evidence of a movement's anti-democratic and anti-Semitic persuasion, if not also their irrationality, paranoia, and extremism which hold the potential for violence. According to Mark Fenster in Conspiracy Theories: Secrecy and Power in American Culture (1999), "the term 'conspiracy theory' serves as a strategy for delegitimization in political discourse. [... it] has come to represent a political Other to a 'proper' democratic politics". ${ }^{18}$ The fact that movements who have committed acts of terrorism also have a penchant for conspiracy theories and the targets of the former tend to be the scapegoats in the latter completes the circle of evidence. According to Chip Berlet, the employment of conspiracy theory and inclination towards conspiracism by social and political movements and activists has historically been used by the state, law enforcement agencies, watchdog groups and commentators to represent them as irrational, paranoid and a threat to the liberal consensus if not also the government, nation and/or democracy itself, and thereby not only demonize and de-legitimize them and their political causes, but also justify repressive state measures. ${ }^{19}$

It is thus unsurprising that during periods when oppositional social and political movements that engage in conspiracy theory are on the rise or in the news, there is a proliferation in books, articles, and commentaries about conspiracy theory which demonize it and its adherents. Peter Knight, a critic of such demonization like Berlet, argues that "the prominence of conspiracy theories in American politics and culture has generated much anxious discussion in recent years, not least in the aftermath of the Oklahoma bombing and its panicked revelations about the rise of the paranoia-promoting militias". ${ }^{20}$ In this case, Knight is referring specifically to the work of Daniel Pipes in Conspiracy: How the Paranoid Style Flourishes and Where It Comes From (1997). This pattern, he holds, occured again in the aftermath of 9/11 with more writing from Pipes and Aaronovitch, but has its roots in Richard Hofstadter's "The Paranoid Style in American Politics". Berlet cites Hofstadter's essay as the foundational text for this delegitimation of conspiracy theory, particularly its psychopathologization, which exerted a great influence on Pipes as his title indicates. Hofstadter's piece was first published in Harper's Magazine in 1964 in the context of civil rights, the cold war, and at the same time as the FBI's COINTELPRO was investigating and trying to suppress both the Klan and the left. In it, Hofstadter argued that conspiracy theory is a combination of "distorted judgment" and "demonological fervor". 21

\footnotetext{
${ }^{18}$ Mark Fenster, Conspiracy Theories: Secrecy and Power in American Culture, Minneapolis 1999, p. xiii.

${ }^{19}$ Cf. Chip Berlet, "Three Models for Analyzing Conspiracist Mass Movements of the Right", in: E. Ward (ed.), Conspiracies: Real Grievances, Paranoia, and Mass Movements, Seattle 1996, pp. 47-50.

${ }^{20}$ Peter Knight, Conspiracy Culture: From Kennedy to the 'X-Files', London 2000, p. 5.

${ }^{21}$ Richard Hofstadter, "The Paranoid Style in American Politics", in: The Paranoid Style in American Politics and Other Essays, London 1966, pp. 3-40.
} 
Pipes' Conspiracy picks up on Hofstadter's "paranoid style" and defines conspiracy theory as a "fear of a non-existent conspiracy", ${ }^{22}$ thus confirming the irrationality, instability, and illegitimacy of the theory and theorist within the very definition. Although Pipes was responding to the rise of the American extreme-right in the 1990s and used Hofstadter's thesis, written in response to McCarthyism in the 1950s and examining what he saw as a particularly American phenomenon with a far longer history, Pipes states that he happened upon the topic of conspiracy theories when he was writing about their prominence in the Middle East in his study The Hidden Hand. ${ }^{23}$ Writing about conspiracy theory and alliances between Islam and the extreme-right following 9/11 thus brought Pipes full circle and allowed him to bring the two movements together. In the latter book, Pipes cites Hitler and Stalin as examples of the danger posed by conspiracism. ${ }^{24}$ Linking conspiracism to two symbols of evil in the twentieth century, it becomes by example, if not also by definition, anti-democratic, anti-Semitic, genocidal and both right and left. According to Pipes, the contemporary targets of conspiracists include the democratic governments of Britain, America, and Israel, ${ }^{25}$ with the latter representing the relation between conspiracy theory, antidemocracy, and anti-Semitism.

The key theme of conspiracy theory which links it to both the extreme-right and Islamism is antiSemitism. This link is based on the prevalence of anti-Semitism in conspiracy theories and the penchant for conspiracy theories amongst anti-Semitic movements (e.g. the extreme-right and Islamism). Differentiating between two types of conspiracy theory - those about secret societies from the crusades and those about Jewish conspiracies such as the Protocols - Pipes argues that modern conspiracy theory is fueled by antiSemitism. This argument has been pushed even further by Leonard Zeskind who holds that the Protocols are not only the source and foundation for modern conspiracy theory, but also anti-Semitism. ${ }^{26}$ Conspiracy theory is not only anti-Semitic in terms of content and history, he argues, it is itself "structurally antiSemitic" ${ }^{27}$ Thus, the mere presence of conspiracy theory is used as evidence of anti-Semitism, and each is seen as constitutive of the other.

Berlet develops on the relationship between racism, anti-Semitism, extremism, violence and conspiracy theory in his essay "Three Models for Analyzing Conspiracist Mass Movements of the Right" (1996) and his report for Political Research Associates (PRA) Toxic to Democracy: Conspiracy Theories, Demonization, \& Scapegoating (2010). Both texts were written in response to the proliferation of conspiracy theories and right-wing extremism leading up to and following the Oklahoma City bombing in the case of the former and following both $9 / 11$ and the election of Obama in the case of the latter. ${ }^{28}$ For

\footnotetext{
${ }^{22}$ Daniel Pipes, Conspiracy: How the Paranoid Style Flourishes and Where it Comes From, New York 1997, p. 21.

${ }^{23}$ Cf. Pipes, Conspiracy, p. xii.

${ }^{24}$ Cf. Pipes, Conspiracy, p. xi.

${ }^{25}$ Cf. Pipes, Conspiracy, p. xi.

${ }^{26}$ Cf. Leonard Zeskind, "Some Ideas on Conspiracy Theories for a New Historical Period", in Ward, Conspiracies, pp. 16-17.

${ }^{27}$ Zeskind, "Some Ideas", p. 17.

${ }^{28}$ Cf. Berlet, "Three Models"; Berlet/PRA, Toxic to Democracy: Conspiracy Theories, Demonization, \& Scapegoating, June 2010, www.publiceye.org (accessed Oct. 12, 2010).
} 
Berlet, conspiracism is "[a] distinct narrative form of scapegoating, [...] [that] uses demonization to justify constructing the scapegoats as wholly evil while reconstructing the scapegoater as a hero. [It] [s]ees secret plots by tiny cabals of evildoers as the major motor powering important historical events". ${ }^{29}$ Moreover, he views conspiracy theories as "tools of fear", rooted in and drawing on anti-Semitism and racism, which "build structures of violence" that are directed towards these scapegoated groups. ${ }^{30}$ Unlike Hofstadter and Pipes, however, Berlet does not demonize or psychopathologize conspiracy theories and theorists, but argues that they constitute reified symptoms - not causes - of underlying social tensions, and that the basis of the grievances needs to be revealed and resolved. ${ }^{31}$

While Berlet, as a left-wing progressive, tries to recover material reality from the conspiracy theory, Mark Fenster tries to recover conspiracy theory for left-wing progressive politics. Fenster argues that conspiracy theory articulates a populist antagonism between "the people" and "power" by critiquing the dominant political order and its representation of reality. It represents both an expression of contemporary subjectivity as well as a condition of political insignificance and the manifestation of political life "in-significance" and asserts the utopian desire for political transparency, which could make it a critical vehicle for the left or progressives. ${ }^{32}$ The problem, Fenster concludes, is that because of their criticism of the war on terror and Israel, the left and their conspiracy theories also become targets for Aaronovitch, Pipes, and neo-conservatives such as David Horowitz, along with Islamists and the extremeright. $^{33}$

If attempted alliances between the latter two are indeed unidirectional, unsuccessful, and the function of such overtures is coattail-riding, as Michael has argued, and if one agrees with Fenster that conspiracy theories are about political "in-significance", then the extreme-right's attempted alliances are of the same order as their conspiracy theories. This is not because such attempts prove an alliance, but because they are both about political insignificance and the fantasy of being IN-significance (as a movement). As I have already suggested, they occur at specific moments in American post-war history when the extremeright is experiencing a period of realignment or crisis in which they are seeking to establish their relevance and which corresponds almost directly to developments in American foreign policy that relate to the Middle East and Islam. The realignment or crisis in question may also be brought on by the mere fact that the extreme-right and the domestic issues which concern or interest them are marginalized in favor of more pressing or high profile foreign policy issues and interests in the Middle East or involving Muslims or Arabs, such as 9/11. Because the extreme-right is traditionally anti-Semitic, American foreign policy in the Middle East, Arab or Muslim world, and conflicts that involve Israel or its "enemies" are highlighted and

${ }^{29}$ PRA, "Big Glossary”, Public Eye, http://www.publiceye.org/glossary/glossary_big.htm (accessed July 21, 2002).

${ }^{30}$ PRA, "PRA Releases New Study, Toxic to Democracy", June 4, 2009

www.publiceye.org/conspire/toxic2democracy/media.html (accessed Oct. 12, 2010); Toxic to Democracy, p. 5.

${ }^{31}$ Cf. PRA, "Big Glossary".

${ }^{32}$ Fenster, Conspiracy Theories, pp. vii-xiv, 55-59.

${ }^{33}$ Cf. Pipes, "The Left Love CAIR, MPAC, et al.", www.danielpipes.org, Aug. 19, 2003; David Horowitz, Unholy Alliance: Radical Islam and the American Left, Washington 2004. 
made relevant. The extreme-right attempts to establish alliances with Arabs, Muslims and Islamists at such moments in order to insert themselves into the political landscape and a position of significance. Yet, in the absence of such alliances or recognition in reality, they construct conspiracy theories in which they present themselves as agents, targets, or merely theorists who have access to the truth. This function has a parallel in the work of many of those who use the extreme-right's penchant for conspiracy theory to suture the gaps in their narrative of alliances when the reality is that these attempted alliances have been unsuccessful. In a sense, both want real alliances, but all there may be are conspiracy theories. In order to illustrate this thesis, in the next section, I will examine five periods in the post-war history of extreme-right conspiracy theories about and attempted alliances with Islamists and the wider Arab and Muslim world.

\section{Part 2: Conspiracy Theories, Alliances, and Axes in History}

\section{Post-War}

For American fascist organizations, such as the National Renaissance Party (NRP), the German-American Bund, and William Dudley Pelley's Silver Shirts, who had been on the rise during the depression, but were seriously diminished by the anti-fascist Brown Scare following Pearl Harbor and America's entrance into the war, the defeat of the Nazis and establishment of Israel represented serious blows. Yet, these events mapped easily on to existing conspiracy theories about Jewish plots for global power, such as the Protocols and Ford's 'The International Jew', which was circulated by the Klan and American fascists prior to and throughout the war. ${ }^{34}$ While the establishment of Israel could be integrated into existing theories, it also represented a paradigm shift in anti-Semitic theories and representations, as the traditional diasporic stateless Jew was replaced by one with formal political power and military might in a new post-war global order.

With world powers realigning in the post-war, and later cold war, period, not only did America want a foothold and allies in the Middle East (e.g. Israel), but so did the extreme-right. In the late 1940s and early 1950s, Gerald L. K. Smith of the Union Party, America First Committee/Party, and Christian Nationalist Crusade/Party met with a representative of the Egyptian embassy, and Robert Williams, a former military intelligence officer and pioneer of Holocaust denial, met with a Syrian Minister to discuss the translation of his writings on the "Jewish Problem" into Arabic. ${ }^{35}$ Also in the 1950s, the NRP which, like other American fascist organizations, had declared its support for National Socialism against Jewish communism, now expressed support for Stalin as a bulwark against the international Jewish "menace" and extended that support to the Middle East, including the Baathists in Iraq and Nasser's progressive nationalism in Egypt. The NRP even sold Nasser's publications in America and invited Egyptian UN press

\footnotetext{
${ }^{34}$ Cf. Martin Durham, White Rage: The extreme-right and American politics, London 2007, p. 12.

${ }^{35}$ Durham, White Rage,. pp. 14, 16.
} 
attaché Abdul Mawgoud Hassan to speak at their meeting. ${ }^{36}$ The NRP also looked closer to home, establishing links with the Greenshirts, a New York based Islamist group led by white convert John Hassan and inspired by the Muslim-Bosnian SS who were endorsed by the Grand Mufti of Jerusalem. ${ }^{37}$ The NRP saw Muslim and Arab movements as the frontline of resistance against colonialism and other newer forms of global imperialism such as Zionism. ${ }^{38}$ In fact, the NRP were calling for a nationalist revolution in the third world and linked it to the anti-colonialism of the American Revolution, thus making America and American movements (including themselves) relevant. According to the NRP, these revolutionaries in the third world want: "to throw off the oppressive yoke of foreign colonialism just as our heroic American ancestors rebelled against the unjust taxation and repressive laws of the British Empire in 1776". ${ }^{39}$

In spite of courting movements in the Middle East and Arab and Muslim world, the extreme-right received very little response or reciprocation. Instead, those with whom the extreme- right did form links or alliances were domestic American Muslim groups such as the Greenshirts, and in the case of George Lincoln Rockwell's American Nazi Party (ANP), the organization most widely cited for forming alliances with Muslims, it was the Black American Nation of Islam (NOI). Although Rockwell also allegedly made overtures to United Arab Republic President Gamal Abdel Nasser in $1959,{ }^{40}$ it was his speech at a NOI rally in 1961 and attendance at their 1962 convention that are most often used as evidence of his alliance with Muslims. ${ }^{41}$ The example also testified to the ANP's focus on domestic American politics - in fact they had rejected the NRP for its anti-Americanism,$-{ }^{42}$ and domestic developments that concerned race and which not only overshadowed international issues but also made the extreme-right relevant again. In this case, these domestic developments were battles over desegregation and civil rights in the 1950s and 1960s

\section{Post-Civil Rights}

With the passing of the Civil Rights Act in 1964, the extreme-right entered a decisive period. The Civil Rights Act appeared to represent the end of white supremacy that the ANP, Klan, and others had mobilized to defend. At the same time, the Klan was under investigation by the FBI's COINTELPRO and the HUAC, which published its indictment of the Klan in $1967,{ }^{43}$ the year that Rockwell was assassinated. Such developments saw the movement marginalized, without a cause and in search of a new direction. Events in the Middle East, such as the 1967 Arab-Israeli War, expansion of Israel with US support, and the Middle East becoming a major cold war front, provided material. For an already anti-Semitic extreme-right, they

\footnotetext{
${ }^{36}$ Nicholas Goodrick-Clarke, Black Sun: Aryan Cults, Esoteric Nazism and the Politics of Identity, New York 2002, pp. 78-79.

${ }^{37}$ Cf. Goodrick-Clarke, Black Sun, pp. 78-79; Durham, White Rage, p. 19

${ }^{38}$ Cf. Goodrick-Clarke, Black Sun, pp. 78-79.

${ }^{39}$ Durham, White Rage, p. 19.

${ }^{40}$ Cf. Michael, The Enemy of My Enemy, p. 124.

${ }^{41}$ Cf. Durham, White Rage, p. 21.

${ }^{42} \mathrm{Cf}$. Durham, White Rage, p. 21.

${ }^{43}$ Cf. US Government, The Present-Day Ku Klux Klan Movement, Hearings before the Committee On UnAmerican Activities, House of Representatives, Ninetieth Congress, Dec. 11, 1967.
} 
confirmed the belief in a Zionist plot for domination of America and the world and allowed for the incorporation of Israel and the Middle East into existing anti-Semitic conspiracy theories and the creation of new ones. It was at this time that the extreme-right picked up the conspiracy theory "The Soviet-Israelite Class Strangles the Arabs" (1969) by Polish anti-Semite Louis Bielsky, in which he outlines the plans that "Jewish imperialism and the communist revolution have for the conquest of the Arab states and the Islamic world". ${ }^{4}$

The direction of the extreme-right was also greatly influenced by developments within the movement itself. One significant example occurred in 1973, the same year as the next Arab-Israeli War and oil crisis which hit closer to home, when William Pierce, a former ANP member and editor of their National Socialist World, took over the National Youth Alliance (NYA). ${ }^{45}$ The NYA was formed the year after Rockwell's assassination in 1968 to counter the student movement on the left, but had also been subject to battles over the future of National Socialism, between an American-style national socialism of Rockwell and Willis Carto and a German style-national socialism of Francis Yockey. ${ }^{46}$ Under Pierce, the former was adopted and American foreign policy became one of the NYA's key interests. Israel in particular became a more significant issue following the 1967 and 1973 wars respectively and the oil crisis. In 1973, the NYA testified before the Senate Committee on Foreign Relations, arguing that Henry Kissinger should not be appointed Secretary of State as he would support Israel over America. ${ }^{47}$

The following year, the NYA was renamed the National Alliance which would become infamous for Pierce's advocacy of an anti-government insurgency and his novel The Turner Diaries, which at least partially inspired the Oklahoma City bombing in 1995. Pierce's enmity with the government and his calls for an armed insurgency were part of a wider trend amongst the extreme-right in the 1970s and early 1980s, as it was trying to adapt to the post-civil rights era. While Klansman David Duke pursued a mainstreaming electoral strategy, another Klansman, Louis Beam, would issue his call-to-arms "where ballots fail, bullets will prevail". ${ }^{48}$ What followed in the wake of Beam's appeal was the paramilitarization of the Klan and emergence of a new breed of insurgent anti-government, anti-Semitic white supremacist and separatist groups such as Posse Comitatus, Aryan Nations, The Order, The Covenant, the Sword and the Arm of the Lord, and White Aryan Resistance.

It was at this time that conspiracy theories concerning the Zionist Occupied Government (ZOG) controlling the United States became prominent and pervasive. ZOG, which exemplified the post-war shift from the traditional representation of the diasporic Jew to that of a contemporary political force seeking global political domination, was popularized by the Christian Identity movement, ${ }^{49}$ which had a long-

\footnotetext{
${ }^{44}$ Louis Bielsky, “The Soviet-Israelite Class Strangles the Arabs", in: Donald T. Critchlow et al. (ed.), Political Conspiracies in America: A Reader, Bloomington 2008, pp. 130-133.

${ }^{45}$ Cf. Durham, White Rage, p. 27.

${ }^{46}$ Cf. Durham, White Rage, p. 27.

${ }^{47}$ Cf. Durham, White Rage, p. 27.

${ }^{48}$ James Ridgeway, Blood in the Face: The Ku Klux Klan, Aryan Nations, Nazi Skinheads, and the Rise of a New White Culture, New York 1990, p. 87.

${ }^{49}$ Cf. Durham, White Rage, p. 69.
} 
standing interest in Israel and Zionism. Its anti-Semitic religion had been popular amongst national socialists of the pre- and post-war period with adherents such as Gerald L.K. Smith and the Silver Shirts and came to dominate the post-civil rights era through adherents such as Beam, William Potter Gale, and former Silver Shirt Richard Butler, who was a member of Posse Comitatus, founder of Aryan Nations and mentor to The Order. The Christian Identity movement has its theological roots in nineteenth century British Israelism which migrated to the US in the 1930s, taking the name Christian Identity and becoming popular amongst the extreme-right. ${ }^{50}$ According to Identity theology, Aryans are Yahweh's chosen people, the offspring of the original tribes of Israel, and hence the true Israelites, who have been spread across the world, wandering in search of the Promised Land. ${ }^{51}$ In the American version, the US is depicted as the "NEW JerUSAlem". 52 Jews, on the other hand, are neither the true Israelites nor God's chosen people, but the spawn of the serpent (or Satan) who have no legitimate claim on Palestine or America. ${ }^{53}$ They have not only occupied Israel/Palestine, but seek to extend their power globally and over the USA in particular, leaving the Aryans without a nation. This not only makes the US more central, it also reverses the logic of anti-Semitism, portraying Aryans as the diasporic stateless other and Jews as political oppressors, imperialists, and fascists. This is exemplified in Identity Pastor William LeGrande's theory that "Jewish 'Fascism' Governs the U.S.A.”, ${ }^{54}$ and Aryan Nations' R. F. Masker's "International Marxist/Zionist Program for World Domination", in which the Protocols inspired "International Rabbinical Talmudism" meets "International Political Zionism" to form a "Zionist Controlled One-World Government". 55

In addition to promoting ZOG conspiracy theories, Identity activists also attempted to establish alliances with Islamists. According to Richard Scutari of The Order, in 1984 the group met with members of the Egyptian Islamic Group who were responsible for the 1981 assassination of Anwar Sadat ${ }^{56}$ It was also alleged that Order leader Robert Mathews approved a plan to seek funding for their white revolution from oil-rich Arab countries, but Michael states that little is known about their progress or if the plan was a fabrication or pipe dream. ${ }^{57}$ Another example of an attempted alliance between Identity activists and movements in the Middle East and Arab and Muslim world occurred in 1989 when Louis Beam announced the formation of the New Right, an alliance between the American extreme-right and "liberation movements" against Zionism in Syria, Libya, Iran, and Palestine. ${ }^{58}$ Although remaining unrealized, Beam's attempt to ally himself and his cause with movements in the Middle East occurred at a significant time

\footnotetext{
${ }^{50}$ Cf. Durham, White Rage, p. 67.

${ }^{51}$ Cf. Betty Dobratz/Stephanie L. Shanks-Meile, The White Separatist Movement in the United States, Baltimore 2000, p. 76.

${ }_{52}$ Durham, White Rage, p. 67.

${ }^{53}$ Cf. Dobratz/Shanks-Meile, The White Separatist Movement, p. 76.

${ }^{54}$ William S. LeGrande, “Jewish 'Fascism' Governs the U.S.A.”, in: Calling Our Nation, 41, pp. 9-10.

${ }^{55}$ R. J. Masker, "International Marxist/Zionist Program for World Domination”, in: Calling Our Nation, 54, p. 15.

${ }^{56}$ Cf. Michael, The Enemy of My Enemy, p. 31.

${ }^{57} \mathrm{Cf}$. Michael, The Enemy of My Enemy, p. 31.

${ }^{58}$ Nicholas Chriss, "Beam Says His 'New Right' Has Middle East Links”, in: Houston Chronicle, Apr. 2, 1989, p. 16A.
} 
when the region became more central in American foreign policy and political debates with the end of the cold war, Gulf War, and "Clash of Civilizations". 59

\section{Post-Cold War}

The Gulf War of 1990-1991 would prove a significant factor in increasing extreme-right enmity toward the government and mainstream right, as well as providing further material for conspiracy theories. President George H. W. Bush's decision to go to war against Iraq, an enemy of Israel, in defense of Kuwait, split the right between the neo-conservatives supporting it and paleo-conservatives, such as Pat Buchanan, as well as extreme-right activists, such as David Duke, opposing it as a Zionist war. ${ }^{60}$ The notion that America was fighting a Zionist war was something that extreme-right conspiracy theorists believed was proven by the Jewish presence in the neo-conservative movement, which they believed was gaining too much of an influence over American foreign policy. This was an issue that originally came up in the 1970s when the Liberty Lobby expressed concerns over an alleged Jewish infiltration of conservatism, ${ }^{61}$ and would come up again following the Oklahoma City bombing and during the war on terror. In response to the Gulf War, Garry Schroeder of Posse Comitatus went to the Iraqi embassy in Washington DC to protest, while Oklahoma Klansman Denis Mahon organized a demonstration in support of Saddam Hussein in Tulsa. ${ }^{62}$ According to George Michael, "like previous attempts to build alliances in the Middle East, the extreme right's support for Saddam Hussein appears to have produced few tangible results". ${ }^{63}$

At the same time as the Gulf War, Bush's gave his "New World Order" speech on September 11, $1990 .{ }^{64}$ In the absence of the communist evil empire following the end of the cold war, Bush's speech was seen as an announcement of its replacement by a New World Order led by ZOG. In fact, a Patriot monthly at the time claimed that the Protocols were "the blueprint used for the New World Order" ${ }^{65}$ Evidence for the New World Order included not only the war, but the FBI/ATF sieges at Ruby Ridge, the Idaho home of Randy Weaver, in 1992 and the Branch Davidian compound in Waco, Texas in 1993. This led to a significant backlash by the extreme-right which included the emergence of the militia movement and the Oklahoma City bombing by Gulf War veteran Timothy McVeigh. He claimed that his attack was a "retaliatory strike" for the actions of the federal government at Ruby Ridge and Waco, ${ }^{66}$ and that his experience as a soldier in the Gulf War, Iraqi deaths, and US foreign policy in the Middle East informed his beliefs and activism. ${ }^{67}$

${ }^{59}$ Samuel P. Huntington, 'The Clash of Civilizations?', in: Foreign Affairs, 72/3, Summer 1993, pp. 22-49

${ }^{60}$ Cf. Durham, White Rage, p. 121; Michael, The Enemy of My Enemy, pp. 288-289.

${ }^{61} \mathrm{Cf}$. Durham, White Rage, p. 123.

${ }^{62}$ Cf. Michael, The Enemy of My Enemy, p. 138; Lee, "The Swastika and the Crescent".

${ }^{63}$ Michael, The Enemy of My Enemy, p. 138

${ }^{64}$ Sara Diamond, Roads to Dominion: Right-Wing Movements and Political Power in the United States, New York 1995, p. 286.

${ }^{65}$ Durham, White Rage, p. 137.

${ }^{66}$ SPLC, "Bombs, Bullets, Bodies: The Decade in Review", in: Intelligence Report 97/2000, p. 21.

${ }^{67}$ Cf. Michael, The Enemy of My Enemy, p. 135. 
Following his conviction, McVeigh spoke out against US foreign policy, including the 1998 missile strikes on Afghanistan and Sudan following al-Qaeda bombings in Kenya and Tanzania. On April 21, 2001, he also expressed approval of Ramzi Yousef's 1993 attack on the World Trade Center. ${ }^{68}$ In a conspiracy theory about an alliance between the extreme-right and Islamists, this attack and McVeigh's Oklahoma City bombing have been linked together. This conspiracy theory originated in McVeigh's lawyer Stephen Jones's investigation and book Others Unknown: Timothy McVeigh and the Oklahoma City Bombing Conspiracy (1998) and the documentary Conspiracy? The Oklahoma City Bombing (2007). The documentary also attempts to incorporate $9 / 11$, which occurred a mere three months after McVeigh was executed by lethal injection at Terre Haute Indiana Federal Prison on June 11, 2001, by asking if there is a "single thread that ties [all three of] them altogether?" ${ }^{99}$ This conspiracy theory tries to prove that Oklahoma City, the only one of the three not involving al-Qaeda, was committed by them, negating the aberration and establishing continuity. Evidence for such a link includes eyewitness accounts of two Middle Eastern looking men, one of whom was alleged to be the suspect John Doe 2, who were in the vicinity, but sped off in a car before the blast. The theory also argues that McVeigh and his accomplice Terry Nichols had little experience with bombs and thus could not have executed the plot without help. The fact that the same method of attack was used in the first World Trade Center attack and the Oklahoma City bombing - Ryder trucks with ammonia nitrate bombs - is taken as proof of al-Qaeda's involvement. The theory also claims that Nichols traveled to the Philippines to meet with Yousef and Abu Sayyaf and receive bomb making training. ${ }^{70}$

In another theory, Jayna Davis, a former reporter for KFOR-TV in Oklahoma City, claimed that the Iraqi government was involved in the bombing. She argued that former Iraqi Republican Guard Hussain Hashem al-Hussaini met with McVeigh and was in fact the mysterious John Doe $2 .^{71}$ The extreme-right American Free Press suggested, in return, that Davis had been duped into believing Arabs were behind the bombing, when it was the Israelis. The paper argued that the Iraq connection theory was propagated by Jewish neo-conservatives such as Paul Wolfowitz in an attempt to justify an invasion back in the $1990 \mathrm{~s}^{72}$ While McVeigh accepted full responsibility and never implicated al-Qaeda, he and the extreme-right were soon overshadowed by the events of $9 / 11$.

\section{Post-9/11}

${ }^{68} \mathrm{Cf}$. Michael, The Enemy of My Enemy, p. 135.

${ }^{69}$ History Channel, Conspiracy? Oklahoma City Bombing, A\&E, 2007.

${ }^{70}$ Cf. History Channel, Conspiracy; Stephan Jones/Peter Israel, Others Unknown: Timothy McVeigh and the Oklahoma City Bombing Conspiracy, New York 1998.

${ }^{71} \mathrm{Cf}$. Michael, The Enemy of My Enemy, pp. 132-133.

${ }^{72}$ Cf. Michael, The Enemy of My Enemy, pp. 134-135. 
Following the Oklahoma City bombing, the extreme-right had the eyes of the nation on them: senate subcommittee hearings on domestic terrorism and extremism were held from 1995 to $1996,{ }^{73}$ books written, and anti-terror legislation was passed. ${ }^{74}$ Yet, increased pressure, aging leadership, lawsuits, and a lack of purpose pushed them into the political wilderness, which 9/11 and the focus on Islamist extremism would compound. Some extreme-right activists criticized the attacks on $9 / 11$, such as a contributor to the Stormfront website who stated that although he opposed "Jewish schemes" like Islamists, "no one who flies airplanes full of ARYANS into buildings full of ARYANS is a friend of the ARYANS". ${ }^{75}$ The majority, however, were more in line with the National Alliance's Billy Roper who has been quoted above. There were many more such statements which, like Roper's, explicitly acknowledged that the extreme-right had been overshadowed, feared obsolescence, and were eager to ride al-Qaeda's coattails and enter the battlefield. For example, Rocky Suhayda of the American Nazi Party said:

[W] hat's wrong with just ACCEPTING the FACT that a HANDFUL of VERY BRAVE PEOPLE were WILLING TO DIE FOR 'WHATEVER' THEY BELIEVED IN [...] and DID IT? [...] All I can say is that it's a DISGRACE that in a population of at least 150 MILLION 'White/Aryan Americans' [...] we provide so FEW that are willing to do the same. [...] [A] bunch of 'towel head/sand niggers' put our great 'White Movement' to SHAME. ${ }^{76}$

In similar fashion, Paul R. Mullet of Aryan Nations declared:

[T] he current events in Jew York city have caused me to activate my unit. We are preparing a strike here in Minnesota and other surrounding areas. Please be advised that the time for ALL ARYANS TO ATTACK IS NOW NOT LATER. Our opportunity may never be the same. ${ }^{77}$

Following from such statements, there were numerous attempts by the extreme-right at alliances building. The most notable and vocal example was Aryan Nations. The organization had been prominent and influential in the 1980s and 1990s, but between the Oklahoma City bombing and 9/11 it had lost its compound to a Southern Poverty Law Center (SPLC) lawsuit and experienced leadership struggles. With founder Richard Butler in ill health at the time of 9/11, a breakaway faction led by former webmaster August Kreis attempted to grab the momentum by trying to establish an alliance with al-Qaeda. Soon after 9/11, Kreis's website posted the piece "Why Islam Is Our Ally" ${ }^{78}$ While President Bush and others were attempting to differentiate between true moderate Islam and extremist Islam, Kreis argued that it is "the

${ }^{73}$ Cf. Combating Domestic Terrorism; The Militia Movement in the United States and Nature and Threat of Violent Anti-Government Groups In America (1995).

${ }^{74}$ Cf. 1995 Antiterrorism Bill/1996 Antiterrorism Act.

${ }^{75}$ Durham, White Rage, p. 112.

${ }^{76}$ SPLC, "Reaping the Whirlwind".

${ }^{77}$ SPLC, "Reaping the Whirlwind".

${ }^{78}$ SPLC, "Reaping the Whirlwind", p. 79. 
Islam of Al-Qaida, of the Taliban, of Hamas" that is the true and authentic Islam as it rejects compromise with Zionism and the decadence of the West, and that Aryans should respect it just as Hitler had the Grand Mufti of Jerusalem. ${ }^{79}$ Aryan Nations also recommended that Aryans take up arms in support of Muslims, arguing that while a "Turner Diaries scenario" is possible, it was up to Yahweh, because Muslims not Aryans were now the "conduits for his wrath". 80

In the lead-up to the Iraq invasion, Aryan Nations confirmed their willingness to support al-Qaeda with a call for volunteers: "Will the sons and daughters of YHVH God be joining with the zealous soldiers of Mohammed, rising up in righteous indignation?" ${ }^{81}$ In 2005, Kreis announced that "the cells are out there and they are already in place. They may not be cells of Islamic people, but they are here and they are ready to fight" ${ }^{82}$ That same year, Aryan Nations went beyond the offering of mere suicide bombers by creating the position of "Minister of Islamic Liaison" ${ }^{83}$ While nothing came out of any of these offers, they remain central to the alliance thesis.

William Pierce, on the other hand, not only condemned the attacks, but criticized the extreme-right itself for bandwagon-jumping:

We must not foolishly imagine that we can achieve some quick and easy victory by building alliances with people whose goals or interests are essentially different than our own - Middle Easterners or other non-whites for example. ${ }^{84}$

I have no real fondness for anyone in the Middle East. I do not believe that Middle Easterners, Arabs, and Jews - especially Jews - should be permitted to live in America or Europe. I have no sympathy for Islam or any other Semitic religion from the Middle East. ${ }^{85}$

Pierce's fellow Alliance member and successor as host of American Dissident Voices Kevin Strom did express sympathy, if not identification:

It is not the white separatists who are the violent threat to the non white races. [...] It is the Jewish power structure, not white separatists, which routinely pumps Palestinian children full of bullets, tortures them, and keeps them behind barbed wire in what ought to be called concentration camps. It isn't white people who commit drive-by shootings and drug murders in our streets, but the Jewish establishment which has supported the browning of America [...] It's the Jewish

\footnotetext{
${ }^{79}$ SPLC, "Reaping the Whirlwind", p. 79.

${ }^{80}$ SPLC, "Reaping the Whirlwind", p. 79.

${ }^{81}$ SPLC, "Reaping the Whirlwind", p. 79

${ }^{82}$ Qtd. in SPLC, "Reaping the Whirlwind", p. 112.

${ }^{83}$ SPLC, "Reaping the Whirlwind", p. 112; White Rage, p. 79.

${ }^{84}$ Michael, The Enemy of My Enemy, p. 165.

${ }^{85}$ Michael, The Enemy of My Enemy, p. 166.
} 
establishment that insists that no white nation on earth can keep itself white. That's genocide, Palestinians and whites are in the same boat. ${ }^{86}$

While in most of the statements the extreme-right celebrated, supported, and even expressed envy that Islamists committed the 9/11 attacks, most of their conspiracy theories suggested the plot originated elsewhere, with the American government and/or Israel. The belief that the American government was behind the attacks is something that the extreme-right shared with more mainstream 9/11 conspiracy theories such as Loose Change and theorists such as Alex Jones and David Ray Griffin. The extreme-right Free American conceded that bin Laden played a role, but argued that he was used by FEMA to establish a "military police state" and implement counterterrorism measures designed to control opponents of the New World Order. ${ }^{87}$ Mike Piper of American Free Press claimed that "Mossad ultimately orchestrated the 9-11 terrorist attacks in order to spark US outrage against the Arab world" ${ }^{88} \mathrm{He}$ argued that:

on September 11, Israel was faced with world opprobrium for its treatment of the Palestinian uprising, and public opinion was turning against Israel. A small-scale 'suicide' operation (that is, [Israeli operatives] crashing planes into the World Trade Center and pinning the blame on Arabs) would have been a small cost to Israel. ${ }^{89}$

After abandoning his mainstreaming strategy in the 1990s, David Duke now emerged as one of the most vocal of the extreme-right 9/11 conspiracy theorists. According to Duke, al-Qaeda was behind the attack, but Mossad had prior knowledge of it and did not warn the US so that it would retaliate against enemies of Israel in the Middle East. ${ }^{90}$ Duke cites several pieces of 'evidence', including disputes about how many Jews died or were missing, claims that Jews owned the World Trade Center, an alleged witness statement that Mossad agents were seen filming the attacks and had been living near Muhammed Atta. ${ }^{91}$ Duke also charged that US Attorney Michael Chertoff released an Israeli spy ring from prison immediately following 9/11 in order to conceal Israeli complicity. ${ }^{92}$ While Aaronovitch, Pipes, and others attempt to link extreme-right conspiracy theories to those from the left and Islamists, Duke also devotes attention to debunking left-wing conspiracy theories which hold that 9/11was staged by the US government to justify a war for oil, claiming that these theories were created by Jews to divert attention from their plot. ${ }^{93}$

\footnotetext{
${ }^{86}$ Michael, The Enemy of My Enemy, p 289.

${ }^{87}$ Michael Barkun, A Culture of Conspiracy: Apocalyptic Visions in Contemporary America, Berkeley 2003, p. 161.

${ }^{88}$ Michael, The Enemy of My Enemy, p. 229.

${ }^{89}$ Michael, The Enemy of My Enemy, pp. 229-230.

${ }^{90}$ Cf. Michael, The Enemy of My Enemy, p. 230; Kathryn S. Olmsted, Real Enemies: Conspiracy Theories and American Democracy, World War I to 9/11, Oxford 2009, p. 221.

${ }^{91}$ Cf. Michael, The Enemy of My Enemy, p. 230.

${ }^{92}$ Cf. Michael, The Enemy of My Enemy, pp. 190-191.

${ }^{93} \mathrm{Cf}$. Michael, The Enemy of My Enemy, p. 163.
} 
Duke was also one of the few extreme-right activists to not only court Islamists, but be invited to the Middle East, usually to present his conspiracy theories in person. In 2002, Duke gave two lectures in Bahrain, "The Global Struggle against Zionism" and "Israeli Involvement in September 11". ${ }^{94} \mathrm{He}$ also published his conspiracy theory in the Saudi-based Arab News under the title "The Worlds Most Dangerous Terrorist”, appeared on al-Jazeera's Without Borders, ${ }^{95}$ and attended Ahmadinejad's 2006 Holocaust conference. The Duke case is widely taken as the best example of the alliance forged between extremists through conspiracy theory, yet none of those examples constituted a formal alliance beyond the sharing of conspiracy theories.

\section{Obama and Conspiracy Theory}

It may seem surprising that in a country that had been attacked by terrorists and fighting a war on terror, the extreme-right, with its own history of terrorism and attempts to join the conflict, did not make more of an impact on the American security services, media, and popular consciousness. This was in spite of the extreme-right courting Islamists and Pipes and others claiming that the two movements could form or had formed an alliance. There are many possible factors contributing to this lack of impact. Most notably, the extreme-right was already in decline following the Oklahoma City bombing, and 9/11 compounded this and created a prolonged crisis. The reason for this was that in an America under attack, not only were Islamist terrorism and foreign antagonisms more pressing concerns, but as America was also unified by the attack domestic antagonisms were largely ignored. This was particularly the case when the domestic antagonists in question were, as in the case of the extreme-right, white Christian right-wing American terrorists who did not fit easily into a conservative schema in which America was under attack by and at war with foreign, non-white Muslim terrorists.

In this context, the election of Barack Obama as the first African-American President seemed to offer the racist extreme-right an opportunity for relevance. Almost immediately following the election, statements were issued by extreme-right activists such as Thom Robb of the Knights of the Ku Klux Klan who claimed:

It could mean a reawakening of our spirit and blood. Every time the television shows an image of Obama it will be a reminder that our people have lost power in this country. ${ }^{96}$

According to the SPLC, 2007-2008 saw a 4\% rise in hate groups, with over 900 active, and attributed this reversal of the decline experienced since 2000 partly to Obama's election. ${ }^{97}$ The revival of such groups

\footnotetext{
${ }^{94}$ Michael, The Enemy of My Enemy, p. 161.

${ }^{95}$ Michael, The Enemy of My Enemy, p. 161.

${ }^{96}$ SPLC, "In Their Own Words: Hating Barack Obama", in: Intelligence Report, 2009, www.splcenter.org/intel/intelreport/article.jsp?sid=442\&printable=1 (accessed Oct. 12, 2009).
} 
continued through 2008-2009 with the number increasing to $932 .{ }^{98}$ Yet, the greatest increase was with the anti-government patriot movement, which experienced a rise of $244 \%$ from 149 to 512 groups. ${ }^{99}$ Such developments caused the US Department of Homeland Security, which was formed following 9/11 to combat Islamist terrorism, to issue the 2009 report Rightwing Extremism: Current Economic and Political Climate Fueling Resurgence in Radicalization and Recruitment. ${ }^{100}$ There were also growing concerns about the proliferation of anti-government conspiracy theories from The Anti-Defamation League (ADL) in their report Rage Grows in America: Anti-Government Conspiracies (2009), and PRA in Toxic to Democracy. The ADL argue that:

Since the election of Barack Obama as president, a current of anti-government hostility has swept across the United States [...]. What characterizes this anti-government hostility is a shared belief that Obama and his administration actually pose a threat to the future of the United States. Some accuse Obama of plotting to bring socialism to the United States, while others claim he will bring about Nazism or fascism. [...] Some of these assertions are motivated by prejudice, but more common is an intense strain of anti-government distrust and anger, colored by a streak of paranoia and belief in conspiracies. ${ }^{101}$

Although both reports look at extreme-right and mainstream right-wing theories (and theorists), it is the latter that have dominated the post-election period. The loudest voices are not Nazis claiming that Obama is a tool of the Zionists, but the more populist mainstream conservative movements, such as the Tea Party, Freedomworks, and Birther movement, which emerged in the post-election realignment of the right and mobilized support by exploiting conservative fears of Obama, usually planted through conspiracy theories. These theories hold that Obama is a Nazi, socialist, Muslim, or Kenyan, and not American (as the Birthers claim), and thus a threat to America. Interestingly, the claim that Obama is a Nazi and Muslim as well as a socialist plays on the discursive schema that was developed to allege a connection between Nazis and Islamists as well as the left post-9/11. The notion that Obama is a closeted Muslim or sleeper Islamist is widespread in the right-wing press and tied to conspiracy theories about the wider "Islamicization" of America, the most notable proponents of which are Pam Geller and Robert Spencer of Stop Islamicization of America. Specific plots within this alleged conspiracy include the building of the "Ground Zero Mosque", the establishment of Sharia Law in America, and the infiltration of the government and security services by interns from the Council on American-Islamic Relations (CAIR), which is also said to fund or

${ }^{97}$ Cf. David Holthouse, "The Year in Hate", 2009, http://www.splcenter.org/intel/intelreport/article.jsp?aid=1027 (accessed Nov. 19, 2009).

${ }^{98}$ Cf. Mark Potok, "Rage on the Right", 2010, http://www.splcenter.org/get-informed/intelligencereport/browse-all-issues/2010/spring/rage-on-the-right (accessed July 14, 2010).

${ }^{99}$ Cf. Potok, "Rage on the Right".

${ }^{100}$ Cf. Department of Homeland Security, Rightwing Extremism: Current Economic and Political Climate Fueling Resurgence in Radicalization and Recruitment, Apr. 7, 2009.

${ }^{101}$ ADL, Rage Grows in America: Anti-Government Conspiracies, Nov. 16, 2009, http://www.adl.org/special_reports/rage-grows-in-america/default.asp (accessed Nov. 23, 2009). 
function as a front for terrorists. The latter theory is propagated by Daniel Pipes, who had also previously claimed that CAIR is in league with both Hamas and neo-Nazis. ${ }^{102}$ While Pipes is making a link between the extreme-right and Islamists through this theory, he fails to account for what the neo-Nazis may think about the fact that their supposed allies at CAIR are involved with an African-American President, even if he is allegedly Muslim.

Beyond conspiracy theory, such claims about Muslims have had an impact on public and political debates, notably in opposition to the mosque and Sharia law, the latter of which has been the subject of preemptive bans in two states (and attempted bans in sixteen others). ${ }^{103}$ There were also calls from GOP House members to investigate the CAIR intern allegations, ${ }^{104}$ and in 2010 Republican Congressman Peter King, Chairman of the House Homeland Security Committee, held McCarthy-like hearings on "The

Radicalization of American Muslims and response of the community". It seems that the extreme-right has been overshadowed yet again, this time, however, not by Islamist conspiracy theorists, but by Islamophobic conservative ones.

\footnotetext{
${ }^{102}$ Cf. Pipes, "CAIR"; "More Ties"; "CAIR: 'Moderate' Friends of Terror”, New York Post, Apr. 22, 2002, http://www.danielpipes.org/394/cair-moderate-friends-of-terror (accessed Aug. 16, 2010).

${ }^{103}$ Cf. Tim Murphy, “Has Your State Banned Sharia?”, Mother Jones, Feb. 11, 2011, http://www.motherjones.com/mojo/2011/02/has-your-state-banned-sharia (accessed Sept. 5, 2011).

${ }^{104}$ Cf. Glenn Greenwald, "GOP House members call for investigation of Muslim political activity", Salon.com, Oct. 15, 2009, http://politics.salon.com/2009/10/15/investigation/ (accessed Sept. 5, 2011).
} 